\title{
Metabolizable and Net Energy Values of Expanded Cottonseed Meal for Laying Hens and Broiler Chickens
}

Yongfa Liu ${ }^{1}$, Zhibin Ban ${ }^{1,2}$, Peng $\mathrm{Li}^{1}$, Xiaogang Yan $^{2}$, Lijia Li ${ }^{2}$, Dan Liu ${ }^{1}$, Lei Yan ${ }^{1,3}$, and Yuming Guo ${ }^{1}$

${ }^{1}$ State Key Laboratory of Animal Nutrition, College of Animal Science and Technology, China Agricultural University, Beijing, 100193, China

${ }^{2}$ Laboratory of Animal Nutrition Metabolism, Jilin Academy of Agricultural Sciences, Gongzhuling, Jilin, 136100, China

${ }^{3}$ Shandong New Hope Liuhe Group Co., Ltd., Qingdao, 266100, China

Running title: Net Energy for Chickens

Correspondence: Dr. Yuming Guo, State Key Laboratory of Animal Nutrition, College of Animal Science and Technology, China Agricultural University, Beijing 100193, China (email: guoyum@cau.edu.cn) 
Three experiments were conducted to determine the metabolizable energy (ME) and net energy (NE) values of expanded cottonseed meal (ECSM) for broilers aged 14-16 days (Experiment 1), broilers aged 28-30 days (Experiment 2), and 45-week-old Hy-Line Brown hens (Experiment 3). Reference diets based on corn-soybean meal were used to meet the nutritional needs of the birds. The test diets contained ECSM as basis, which was used to replace $18.5 \%$ of the gross energy-yielding ingredients from the reference diet. The birds were fed a commercial feed before the experimental period. After the dietary adaptation period, six birds per replicate (Experiment 1) and two birds per replicate (Experiments 2 and 3) for each treatment group were placed in an individual open-circuit respiratory calorimetry chamber for 3 days. Daily $\mathrm{O}_{2}$ consumption and $\mathrm{CO}_{2}$ production were recorded, and excreta samples were collected. The ME and NE values of ECSM were determined using the substitution method. The apparent metabolizable energy (AME) values of ECSM for experiments 1,2 , and 3 were $2605.85,2178.31$, and $2782.60 \mathrm{kcal} / \mathrm{kg}$ of dry matter (DM), respectively. The NE values were $1655.23,1196.64$, and $1538.19 \mathrm{kcal} / \mathrm{kg}$ of DM, respectively. The NE:AME ratios of ECSM were $63.52 \%, 54.93 \%$, and $55.29 \%$, respectively. Our data showed that the ME and NE values of ECSM differed across various growth stages and types of chickens. These results demonstrate that the appropriate ME and NE should be used in the design of different feed formulas for specific growth stages and types of chickens.

Key words: broilers, expanded cottonseed meal, laying hens, metabolizable energy, net energy 


\section{Introduction}

Accurate evaluation of the effective energy of feed is important for the rational selection of feed raw materials, optimization of the feed formula, and reduction of feed cost. It is worth mentioning that different types of chickens at different physiological stages have different digestive and metabolic statuses. This causes differences in nutrient digestion and utilization of energy from the feed and affects the amount of available energy of feedstuffs. The metabolizable energy (ME) system is widely used in poultry nutrition, but it ignores the contribution of animal heat increment in the processes of feeding, digestion, and metabolism. Previous studies have shown that crude protein triggers the highest heat increment, and fat provokes the lowest heat increment (Hill et al., 1958). Therefore, ME quantification often overestimates the effective energy of a high-protein feed (Carré et al., 2015). The calculation of net energy (NE) is based on the deduction of the heat increment component from the value of ME. Therefore, $\mathrm{NE}$ is more accurate than ME in reflecting the nutritional value of a feed, especially when evaluating protein feedstuffs. In China, cottonseed meal (CSM) is a commonly used protein feedstuff. However, it contains antinutritional factors, such as gossypol, which limit its application. Gossypol can be divided into free gossypol and bound gossypol according to its chemical status (Henry et al., 2001; Mena et al., 2001). CSM can be expanded to create a byproduct feed referred to in this paper as expanded cottonseed meal (ECSM). In this experiment, the processing parameters of ECSM were a screw speed of $150 \mathrm{rpm}$, an expansion temperature of $120^{\circ} \mathrm{C}$, and a moisture content of CSM of $24 \%$. The results showed that the expansion procedure could eliminate free gossypol and other harmful substances of cottonseed. At the same time, 
proteins and starch in the raw materials could isomerize well, and the palatability of CSM was improved significantly, making it easier for animals to digest and utilize (Noftsger et al., 2000; Buser et al., 2002). However, the lack of sufficient studies on the effective energy value of ECSM in poultry limits its proper usage. In this study, the ME and NE values of ECSM were determined by conducting three experiments in chickens of different ages and types.

\section{Materials and methods}

\section{ECSM and diets}

ECSM was obtained from the Xinjiang Province, China. The reference diet consisted of a corn-soybean meal and met the nutritional needs of the animals. The test diets contained ECSM, which was used to replace 18.5\% of the gross energy (GE)-yielding ingredients from the reference diet (as basis). This substitution ratio corresponds to that used by other Chinese researchers working on CSM. The addition of vitamins, minerals, and other non-energy ingredients to the reference and test diets was adjusted for consistency. The birds had ad libitum access to food and water. The moisture content of each ingredient was determined during the preparation of the feed to calculate its contribution to each diet on a dry matter (DM) basis. The ingredients and chemical composition of the diets used in the experiments are presented in Table 1.

\section{Equipment}

An open-circuit respiratory calorimetry instrument of approximately $0.54 \mathrm{~m}^{3}$ was used in this study. This instrument can control temperature and humidity and collect gas on a regular basis to calculate poultry $\mathrm{O}_{2}$ consumption and $\mathrm{CO}_{2}$ production. Inside of it, a cage 
of $70 \mathrm{~cm} \times 55 \mathrm{~cm} \times 70 \mathrm{~cm}$ was placed. The cage was equipped with nipple drinkers and feeders.

Animals and Experimental Design

The study protocol was approved by the Animal Ethics Committee of China Agricultural University (AW02501202-2-1) and the study was conducted in accordance with the guidelines of the Guide for the Care and Use of Agricultural Animals in Research and Teaching.

The number of chickens for each replicate of the experiment was determined according to bird size, the capacity of the chamber, and the concentration of $\mathrm{CO}_{2}$ in the chamber. Birds were selected at approximately equal body weights and randomly assigned to each of the treatment groups in a fully randomized design. During the experimental period, feed intake (FI) was measured, daily $\mathrm{O}_{2}$ consumption and $\mathrm{CO}_{2}$ production were recorded, and total excreta were collected. Feed spillage was measured from the under-cage collection tray and subtracted from FI. Feathers were removed from the collected excreta.

For Experiment 1, Arbor Acres broilers were purchased from a commercial hatchery. Broilers were raised according to a management handbook (Aviagen, 2019) and reared in pens until 10 days of age. On the 11th day, 72 male broilers weighing $300 \pm 15 \mathrm{~g}$ were randomly transferred into each of the 12 respiration chambers for adaptation to feed and the environment. Each diet was administered to broilers in six replicate cages for a 3-day adaptation period followed by a 3-day experimental period (Liu et al., 2017). Feed and water were freely available. The lighting cycle was $20 \mathrm{~h}$ light: $4 \mathrm{~h}$ dark; lighting was switched on at 04:00 and off at 24:00. During the experimental period, FI was measured, 
daily $\mathrm{O}_{2}$ consumption and $\mathrm{CO}_{2}$ production were recorded, and total excreta were collected. ME and NE values were recorded from day 14 to day 16.

For Experiment 2, Arbor Acres broilers were purchased from a commercial hatchery. Broilers were raised according to a management handbook (Aviagen, 2019) and reared in pens until 24 days of age. On the 25th day, 24 male broilers weighing 1,200 $\pm 60 \mathrm{~g}$ were randomly transferred into each of the 12 respiration chambers for adaptation to feed and the environment. Each diet was administered to broilers in six replicate cages for a 3-day adaptation period followed by a 3-day experimental period (Liu et al., 2017). Feed and water were freely available. The lighting cycle was $20 \mathrm{~h}$ light: $4 \mathrm{~h}$ dark; lighting was switched on at 04:00 and off at 24:00. During the experimental period, FI was measured, daily $\mathrm{O}_{2}$ consumption and $\mathrm{CO}_{2}$ production were recorded, and total excreta were collected. ME and NE values were recorded from day 28 to day 30.

For Experiment 3, Hy-Line Brown pullets were purchased from a commercial hatchery. Layers were raised according to a management handbook (Hy-Line, 2018) and reared in pens until 45 weeks of age, when they laid at a $91 \%$ hen/day production. Twentyfour Hy-Line Brown hens were randomly transferred into each of the 12 respiration chambers for adaptation to feed and the environment. Each diet was administered to hens in six replicate cages for a 7-day adaptation period followed by a 3-day experimental period (Ning et al., 2014; Barzegar et al., 2019). The lighting cycle was 16 h light: 8 h dark; lighting was switched on at 04:00 and off at 20:00. During the experimental period, FI was measured, daily $\mathrm{O}_{2}$ consumption and $\mathrm{CO}_{2}$ production were recorded, and total excreta were collected. 
Analyses of Ingredients, Diets, and Excreta

Feed refusals and spillage were collected daily and analyzed for their DM content. For each diet, a feed sample was collected during the experimental period, and its DM content was measured and subsequently used for chemical analyses. Daily excreta samples were stored in a refrigerator at $4^{\circ} \mathrm{C}$. At the end of each period, the excreta collected from each respiratory chamber over 3 days were mixed and dried in an oven at $65^{\circ} \mathrm{C}$ for $72 \mathrm{~h}$. Excreta were left at room temperature, crushed, and then screened. Excreta samples were analyzed for their crude protein $(\mathrm{CP})$, ether extract (EE), crude fiber, ash, neutral detergent fiber, and acid detergent fiber content (AOAC, 2016). The GE contained in the test ingredients, feeds, and excreta was measured using a bomb calorimeter (C2000, IKA, Guangzhou, China) using benzoic acid as a standard. The chemical characteristics of ECSM are shown in Table 2.

\section{Calculations}

Heat production (HP) was calculated using the Brouwer equation (Brouwer et al., 1965):

$$
\mathrm{HP}(\mathrm{kcal})=3.866 \times \mathrm{VO}_{2}(\mathrm{~L})+1.200 \times \mathrm{VCO}_{2}(\mathrm{~L})
$$

where $\mathrm{VO}_{2}$ is the volume of $\mathrm{O}_{2}$ consumed $(\mathrm{L})$ and $\mathrm{VCO}_{2}$ is the volume of $\mathrm{CO}_{2}$ exhaled (L).

The retained energy (RE) was calculated as ME intake (MEI) minus HP.

The AME, AME corrected for zero nitrogen retention (AMEn), and NE of the experimental diets were determined using the following equations:

$\operatorname{AME}(\mathrm{kcal} / \mathrm{kg}$ of DM $)=[(\mathrm{FI} \times \mathrm{GEd})-(\mathrm{E} \times \mathrm{GEe})] / \mathrm{FI}$ 
$\operatorname{AMEn}(\mathrm{kcal} / \mathrm{kg}$ of DM $)=\mathrm{AME}-8.22 \times(\mathrm{Ni}-\mathrm{Ne}) / \mathrm{FI}$

$\mathrm{NE}(\mathrm{kcal} / \mathrm{kg}$ of DM $)=(\mathrm{RE}+\mathrm{FHP}) / \mathrm{FI}$

where FI is the feed intake ( $\mathrm{kg}$ of DM); E is the excreta output ( $\mathrm{kg}$ of DM); GEd is the gross energy of the diet ( $\mathrm{kcal} / \mathrm{kg}$ of DM); GEe is the gross energy of the excreta $(\mathrm{kcal} / \mathrm{kg}$ of $\mathrm{DM}) ; 8.22$ is the nitrogen correction factor for each gram of nitrogen retained in body and eggs (kcal/g; Hill et al., 1958); $\mathrm{Ni}$ is the nitrogen intake from the diet (g/day); $\mathrm{Ne}$ is the nitrogen output through the excreta (g/day); RE is the retained energy and FHP is the fasting heat production. An FHP value of $450 \mathrm{~kJ} / \mathrm{BW}^{0.70}$ per day per bird was used for broilers (Noblet et al., 2015) and an FHP value of $370 \mathrm{~kJ} / \mathrm{BW}^{0.75}$ per day per bird was used for layers (Wu et al., 2016).

The values of AME, AMEn, and NE of the test ingredients were calculated according to the difference method (Barzegar et al., 2019).

AMEingr $(\mathrm{kcal} / \mathrm{kg}$ of DM $)=($ AMEtest - AMEref $\times \mathrm{a} \%) / \mathrm{b} \%$.

NEingr $(\mathrm{kcal} / \mathrm{kg}$ of DM $)=($ NEtest - NEref $\times \mathrm{a} \%) / \mathrm{b} \%$.

where $\mathrm{a} \%$ is the contribution of the energy-yielding ingredients from the reference diet in the test diet and $b \%$ is the substitution level of the ingredients in the test diet. All the ingredients in the diets were converted to DM in order to express the $\mathrm{a}$ and $\mathrm{b}$ values on a DM basis. The energy-yielding ingredients in the reference and test diets included grains, meals, oils, and amino acids. 
The respiratory quotient (RQ) of the birds was calculated as the ratio of the $\mathrm{CO}_{2}$ volume exhaled to the $\mathrm{O}_{2}$ volume consumed by the birds. The heat increment (HI) was calculated by subtracting the FHP from the HP.

\section{Statistical analyses}

The data of production performance, nitrogen balance, and energy metabolism during the 3-day experimental period were analyzed by $t$-test and one-way ANOVA using SPSS statistical software. Differences between treatments were examined using the TukeyKramer test and were considered significant at $\mathrm{P}<0.05$.

\section{Results}

\section{Experiment 1}

The AME, AMEn, and NE values of ECSM were determined as 2605.85, 2245.19, and $1655.23 \mathrm{kcal} / \mathrm{kg}$ of DM, respectively (Table 3). The AME:GE and NE:AME ratios were $55.39 \%$ and $63.52 \%$, respectively.

The test diet containing ECSM significantly increased the body weight gain and Feed conversion ratio $(\mathrm{FCR})$ of broilers $(\mathrm{P}<0.01)$ and significantly decreased their $\mathrm{RQ}(\mathrm{P}<$ 0.01). Nitrogen intake, excretion, and retention were also affected by the test diet. The nitrogen retained in the birds during Experiment 1 was 1.60 and $2.01 \mathrm{~g}$ per bird per day (Table 4). The effects of different diets on energy metabolism in Experiment 1 are shown in Table 5. To correct for the effect of body weight on energy metabolism, the energy metabolism data reported in the table were converted into metabolic body weight $\left(\mathrm{BW}^{0.70}\right)$ consumption. The two diets (reference and test) had no significant effects on GE intake (GEI), AME intake (AMEI), NE intake (NEI), total heat production (THP), and HI in 
broilers. The energy retained as protein was significantly higher in the test diet group than in the reference diet group $(\mathrm{P}<0.01)$, while the energy retained as fat was significantly lower in the test diet group than in the reference diet group $(\mathrm{P}<0.01)$.

Experiment 2

The AME, AMEn, and NE values of ECSM were determined as 2178.31, 1841.53, and $1196.64 \mathrm{kcal} / \mathrm{kg}$ of DM, respectively (Table 3). The AME:GE and NE:AME ratios were $46.32 \%$ and $54.93 \%$, respectively.

The test diet increased body weight gain $(\mathrm{P}<0.05)$, but the average body weight, FI, and RQ were not affected (Table 6). The test diet significantly increased the level of nitrogen metabolism in the broilers $(\mathrm{P}<0.01)$, which showed the same pattern as that observed in Experiment 1. The energy balance data in Table 7 were converted to metabolic body weight, as those from Experiment 1 . The GEI of the metabolic body weight was not influenced by the test diet, but AMEI and NEI were higher $(\mathrm{P}<0.05)$ in broilers fed the test diet than in those fed the reference diet. The RE and REfat values were significantly higher $(\mathrm{P}<0.05)$ in broilers fed the control diet than in those fed the ECSM test diet, while the opposite was true for the REprotein value. The AME, AMEn, NE, and AME:GE ratio values were higher $(\mathrm{P}<0.01)$ in broilers fed the reference diet than in those fed the test diet, while no difference was observed for the NE:AME ratio.

\section{Experiment 3}

The AME, AMEn, and NE values of ECSM for laying hens were determined as 2782.60, 2629.74, and $1538.19 \mathrm{kcal} / \mathrm{kg}$ of DM, respectively (Table 3). The AME:GE and NE:AME ratios were $59.18 \%$ and $55.29 \%$, respectively. 
As shown in Table 8, unlike in broilers, the test diet had no significant effect on the HDP, FCR, $\mathrm{VO}_{2}, \mathrm{VCO}_{2}$, and RQ of laying hens $(\mathrm{P}>0.05)$, but FI was higher for hens on the test diet $(\mathrm{P}<0.05)$. Nitrogen intake and excretion were affected by the test diet, while this had no effect on nitrogen retention.

The test diet affected GEI $(\mathrm{P}<0.05)$ but had no effect on AMEI, NEI, THP, and RE $(\mathrm{P}>0.05)$. Similar to broilers, the test diet influenced the form of energy retained in laying hens and significantly increased the amount of energy retained as protein $(\mathrm{P}<0.05$; Table 9). The AME:GE ratio was higher $(\mathrm{P}<0.01)$ in hens fed the reference diet than in those fed the test diet, but there were no differences in the NE:AME ratio.

\section{Discussion}

The results of the present study showed differences in ME, NE, and energy conversion efficiency in broilers and layers of different age groups. The resulting AME and AMEn values of ECSM in layers were higher than those in broilers, and the ME value was also greater in Experiment 1 (using broilers aged 14-16 days) than in Experiment 2 (using broilers aged 28-30 days). However, the NE value of ECSM in layers was lower than that in 14- to 16-day-old broilers. Thus, the different physiological stages and types of chickens affect the digestion and utilization of the nutrients included in the feed, thereby determining its digestion and utilization. These findings are in agreement with the results of Ryan et al. (1986) and Adeola et al. (2018), who reported that the growth stage and type of chickens influence their digestive efficiency. Adedokun et al. (2015) found that ileal crude protein digestibility and standardized ileal amino acid digestibility for Distillers Dried Grains with Solubles (DDGS) samples was higher $(\mathrm{P}<0.05)$ in 21-day-old broilers than in laying hens. 
Pishnamazi et al. (2005) found that for White Leghorn birds the AMEn digestibility of corn (egg-type birds, $3065 \mathrm{kcal} / \mathrm{kg}$; meat-type birds, $2842 \mathrm{kcal} / \mathrm{kg}$ ), soybean (egg-type birds, $2185 \mathrm{kcal} / \mathrm{kg}$; meat-type birds, $2040 \mathrm{kcal} / \mathrm{kg}$ ), and wheat bran (egg-type birds, 1440 $\mathrm{kcal} / \mathrm{kg}$; meat-type birds, $1333 \mathrm{kcal} / \mathrm{kg}$ ) was significantly greater than that of broiler chickens. Stefanello et al. (2016) reported that the utilization of energy and nitrogen contained in a basal diet decreased when bakery meal was included and increased with the age of broiler chickens. Walugembe et al. (2015) reported that different microbes were found inside different types of chickens fed the same diet: there was a higher concentration of acetic acid and propionic acid in broiler chicks than in laying hen chicks. In a study that characterized the development of amino acid transport in broiler chicks using L-tryptophan, a significant reduction was observed in the uptake rate of $0.04 \mathrm{mM}$ L-tryptophan in both the jejunum and ileum with increasing age (Iji et al., 2001). This could partly explain why the two chicken lines showed differences in digestive efficiency, as reported in our and other studies.

The AME value of ECSM in broilers was lower than the value of $2568 \mathrm{kcal} / \mathrm{kg}$ of DM reported by Zhang et al. (2017). Moreover, the ME and NE of ECSM were higher by 115 $\mathrm{kcal} / \mathrm{kg}$ of DM and $75 \mathrm{kcal} / \mathrm{kg}$ of DM, respectively, than those of soybean meal recorded by Liu et al. (2017). This shows that the feeding value of ECSM was similar to that of a regular soybean meal. Similar results were obtained by Lordelo et al. (2004) and Yuan et al. (2014).

There was a significant increase in the body weight gain of broilers fed the test diet containing ECSM compared with that of broilers fed the reference diet. Sun et al. (2013) 
obtained a positive effect on growth performance by supplementing the diet with $4 \%$ and $8 \%$ fermented CSM. However, some researchers have obtained different results. For example, Abdulrashid et al. (2013) added a CSM formulation to diets in various proportions, and showed that CSM did not affect the body weight gain when it was included in diets at a concentration of up to $30 \%$. Elangovan et al. (2006) did not identify a negative influence of $0 \%$ to $10 \%$ CSM in diets. However, the inclusion of $20 \%$ or $30 \%$ $\mathrm{CSM}$ in isocaloric and isonitrogenous diets can negatively affect the body weight gain, testicular volume, semen volume, and sperm count of broilers (Villalba et al., 2011). In summary, diets supplemented with CSM showed contrasting results. Furthermore, the relatively low concentration of lysine may restrict the quality of proteins in CSM (Watkins et al., 1995; Devanaboyina et al., 2007).

As the CP content of the test diet was higher than that of the reference diet, nitrogen intake and excretion in the test diet group were significantly higher than those in the reference diet group, and the nitrogen retained in the broilers was significantly increased. However, nitrogen retention in laying hens was not significantly affected. These results are consistent with those obtained by Wu et al. (2019) and Barzegar et al. (2020). Nitrogen retention in broilers was higher than that in laying hens; in addition, nitrogen retention in older broilers was higher than that in younger broilers. It is well known that broilers are in the growth phase and thus grow rapidly. Therefore, they require a lot of energy and protein to develop their body tissues. Conversely, laying hens are in the adult stage, show stable body weight, and mainly use their daily intake of energy and nutrients for laying and 
maintenance. Therefore, the energy and nutrient requirements of laying hens are stable (Shapiro et al., 1995; Abdulrashid et al., 2013; Kimiaeitalab et al., 2017).

Furthermore, we observed an interesting phenomenon in the experiments with broilers: the unit body weight deposition energy of the reference diet group was higher than that of the test diet group. This indicates that broilers fed the reference diet need more energy to gain the same weight. Estimating the form of energy deposition revealed that the test diet changed the form of energy deposition; in fact, it increased the proportion of energy deposited as protein and reduced the proportion of energy deposited as fat. Indeed, the energy content of protein per gram was lower than that of fat. Hence, the energy intake of the metabolic body weight in the experimental diet group did not differ from that of the reference diet group. Nevertheless, the efficiency of conversion of effective energy into body weight was improved by the test diet, with increased production performance after a week from the beginning of the experiment.

\section{Acknowledgments}

This work was supported by the China Agriculture Research System (CARS-41-G11), the Shandong Provincial Key Research and Development Program (2019JZZY020602), and the Feedstuffs Net Energy Evaluation Funding provided by Huayu Agri-Tech Co. Ltd., Liaoning Wellhope Agri-Tech Co. Ltd., New Hope Liuhe Co., Ltd., TQLS Group Co., Ltd., and Wens Food Stuff Group Co., Ltd. 


\section{Conflict of Interest}

The authors declare no conflicts of interest.

\section{References}

Abdulrashid M, Joseph ZO, Mohammed A and Adamu HY. Response of broiler chickens fed cottonseed meal based diets. International Journal of Advance Agricultural Research, 2013: 62-65. 2013.

Adedokun SA, Jaynes P, Payne RL and Applegate TJ. Standardized ileal amino acid digestibility of corn, corn distillers' dried grains with solubles, wheat middlings and bakery by-products in broilers and laying hens. Poultry Science, 94: 2480-2487. 2015. Adeola O, Anwar MN, Abdollahi MR and Ravindran V. Age-related energy values of meat and bone meal for broiler chickens. Poultry Science, 97: 2516-2524. 2018. AOAC. Official Methods of Analysis of AOAC International. 20th ed. AOAC International, Rockville, MD, USA. 2016.

Barzegar S, Wu SB, Noblet J, Choct M and Swick RA. Energy efficiency and net energy prediction of feed in laying hens. Poultry Science, 98: 5746-5758. 2019.

Barzegar S, Wu SB, Choct M and Swick RA. Implementation of net energy evaluating system in laying hens: Validation by performance and egg quality. Poultry Science, 
99:2624-2632. 2020.

Brouwer E. Report of sub-committee on constants and facters. In Proceeding of the 3rd Symposium on Energy Metabolism. London, UK. 1965.

Buser MD and Abbas HK. Effects of extrusion temperature and dwell time on aflatoxin levels in cottonseed. Journal of Agricultural and Food Chemistry, 50: 2556-2559. 2002.

Carré B and Juin H. Partition of metabolizable energy, and prediction of growth performance and lipid deposition in broiler chickens. Poultry Science, 94: 1287-1297. 2015.

Devanaboyina N, Rao SVR, Panda AK and Sastry VRB. Cottonseed meal in poultry diets: A review. Journal of Poultry Science, 44: 119-134. 2007.

Elangovan VA, Praveen K T, Shrivastav AK, Pramod KT and Mandal AB. GMO (BtCry1 Ac gene) cottonseed meal is similar to non-GMO low free gossypol cottonseed meal for growth performance of broiler chickens. Animal Feed Science \& Technology, 129: 252263. 2006.

Henry MH, Pesti GM, Bakalli R, Lee J, Toledo RT, Eitenmiller RR and Phillips RD. The performance of broiler chicks fed diets containing extruded cottonseed meal supplemented with lysine. Poultry Science, 80: 762-768. 2001.

Hill FW and Anderson DL. Comparison of metabolizable energy and productive energy determinations with growing chicks. Journal of Nutrition, 64: 587-603. 1958.

Kimiaeitalab MV. Comparative study of the inclusion of sunflower hulls in the diet on growth performance and digestive tract traits of broilers and pullets from 0 to 21 days of age, 96: 581-592. 2017.

Liu W, Liu GH, Liao RB, Chang YL, Huang XY, Wu YB, Yang HM, Yan HJ and Cai HY. 
Apparent metabolizable and net energy values of corn and soybean meal for broiler breeding cocks. Poultry Science, 96: 135-143. 2017.

Iji PA, Saki A and Tivey DR. Body and intestinal growth of broiler chicks on a commercial starter diet. 2. Development and characteristics of intestinal enzymes. British Poultry Science, 42: 514-522. 2001.

Lordelo MM, Davis AJ, Wilson JL and Dale NM. Cottonseed meal diets improve body weight uniformity in broiler breeder pullets. Journal of Applied Poultry Research, 13: 191199. 2004.

Mena H, Santos JEP, Huber JT, Simas JM, Tarazon M and Calhoun MC. The Effects of feeding varying amounts of gossypol from whole cottonseed and cottonseed meal in lactating dairy cows. Journal of Dairy Science, 84:2231-2239. 2001.

Ning D, Yuan JM, Wang YW, Peng YZ and Guo YM. The net energy values of corn, dried distillers grains with solubles and wheat bran for laying hens using indirect calorimetry method. Asian-Australasian Journal of Animal Sciences, 27: 209-216. 2014. Noblet J, Dubois S, Lasnier J, Warpechowski M, Dimon P, Carré B, van Milgen J and Labussière E. Fasting heat production and metabolic BW in group-housed broilers. Animal, 9: $1138-1144.2015$.

Noftsger SM, Hopkins BA, Diaz DE, Brownie C and Whitlow LW. Effect of whole and expanded-expelled cottonseed on milk yield and blood gossypol. Journal of Dairy Science, 83: 2539-2547. 2000 .

Pishnamazi A, Pourreza J, Edriss MA and Samie AH. Influence of broiler breeder and laying hen breed on the apparent metabolizable energy of selected feed ingredients. International Journal of Poultry Science, 4:163-166. 2005. 
Ryan JR, Kratzer FH, Grau CR and Vohra P. Glandless cottonseed meal for laying and breeding hens and broiler chicks. Poultry Science, 65: 949-955. 1986.

Shapiro F and Nir I. Stunting syndrome in broilers: effect of age and exogenous amylase and protease on performance, development of the digestive tract, digestive enzyme activity, and apparent digestibility. Poultry Science, 74: 2019-2028. 1995.

Stefanello C, Vieira SL, Xue P, Ajuwon KM and Adeola O. Age-related energy values of bakery meal for broiler chickens determined using the regression method. Poultry Science, 95:1582-1590. 2016.

Sun H, Tang J, Yao X, Wu Y, Wang X and Feng J. Effects of dietary inclusion of fermented cottonseed meal on growth, cecal microbial population, small intestinal morphology, and digestive enzyme activity of broilers. Tropical Animal Health and Production, 45: 987-993. 2013.

Villalba RM and Smith Y. Differential structural plasticity of corticostriatal and thalamostriatal axo-spinous synapses in MPTP-treated parkinsonian monkeys. The Journal of Comparative Neurology, 519:989-1005. 2011.

Walugembe M, Hsieh JCF, Koszewski NJ, Lamont SJ, Persia ME and Rothschild MF. Effects of dietary fiber on cecal short-chain fatty acid and cecal microbiota of broiler and laying-hen chicks. Poultry Science, 94: 2351-2359. 2015.

Watkins SE and Waldroup PW. Utilization of high protein cottonseed meal in broiler diets. Journal of Applied Poultry Research, 4: 310-318. 1995.

Wu SB, Yang HM, Ban ZB, Yan XG, Zhao YM. Heat production estimated from fasting layer hens at peak lay. World's Poultry congress. Beijing, China. 2016.

Wu SB, Swick RA, Noblet J, Rodgers N, Cadogan D and Choct M. Net energy prediction 
and energy efficiency of feed for broiler chickens. Poultry Science, 98: 1222-1234. 2019. Yuan C, Song H, Zhang X, Jiang Y, Zhang A, Azzam MM and Zou X. Effect of expanded cottonseed meal on laying performance, egg quality, concentrations of free gossypol in tissue, serum and egg of laying hens. Animal Science Journal, 85:549-554. 2014.

Zhang F and Adeola O. Energy values of canola meal, cottonseed meal, bakery meal, and peanut flour meal for broiler chickens determined using the regression method. Poultry Science, 96:397-404. 2017.

\section{Tables}

Table 1. Ingredients and chemical composition of the diets used in the study (in \%)

\begin{tabular}{|c|c|c|c|c|c|c|}
\hline \multirow{2}{*}{ Item } & \multicolumn{3}{|c|}{ Reference diet } & \multicolumn{3}{|c|}{ Test diet } \\
\hline & Expt. 1 & Expt. 2 & Expt. 3 & Expt. 1 & Expt. 2 & Expt. 3 \\
\hline \multicolumn{7}{|l|}{ Ingredient } \\
\hline Corn & 60.82 & 59.35 & 61.20 & 49.57 & 48.37 & 49.88 \\
\hline Soybean meal & 21.42 & 20.60 & 21.50 & 17.46 & 16.79 & 17.52 \\
\hline Corn gluten meal & 2.60 & 2.00 & 3.30 & 2.12 & 1.63 & 2.69 \\
\hline Peanut meal & 3.00 & 4.00 & & 2.45 & 3.26 & \\
\hline Soybean oil & 4.50 & 6.00 & 1.00 & 3.67 & 4.89 & 0.82 \\
\hline DDGS & 3.00 & 4.00 & & 2.45 & 3.26 & \\
\hline $\begin{array}{l}\text { Expanded cottonseed } \\
\text { (ECSM) }\end{array}$ & & & & 17.64 & 17.75 & 16.10 \\
\hline $\mathrm{CaHPO}_{4}$ & 1.14 & 0.70 & & 1.14 & 0.70 & \\
\hline $70 \%$ L-Lys, $\mathrm{HCl}$ & 1.00 & 0.96 & & 1.00 & 0.96 & \\
\hline Sodium chloride & 0.25 & 0.24 & & 0.25 & 0.24 & \\
\hline Sodium humic acid & 0.20 & 0.20 & & 0.20 & 0.20 & \\
\hline D, L-methionine & 0.25 & 0.24 & & 0.25 & 0.24 & \\
\hline L-threonine & 0.14 & 0.15 & & 0.14 & 0.15 & \\
\hline Choline chloride $(60 \%)$ & 0.11 & 0.11 & & 0.11 & 0.11 & \\
\hline Baking soda & 0.12 & 0.01 & & 0.12 & 0.01 & \\
\hline
\end{tabular}




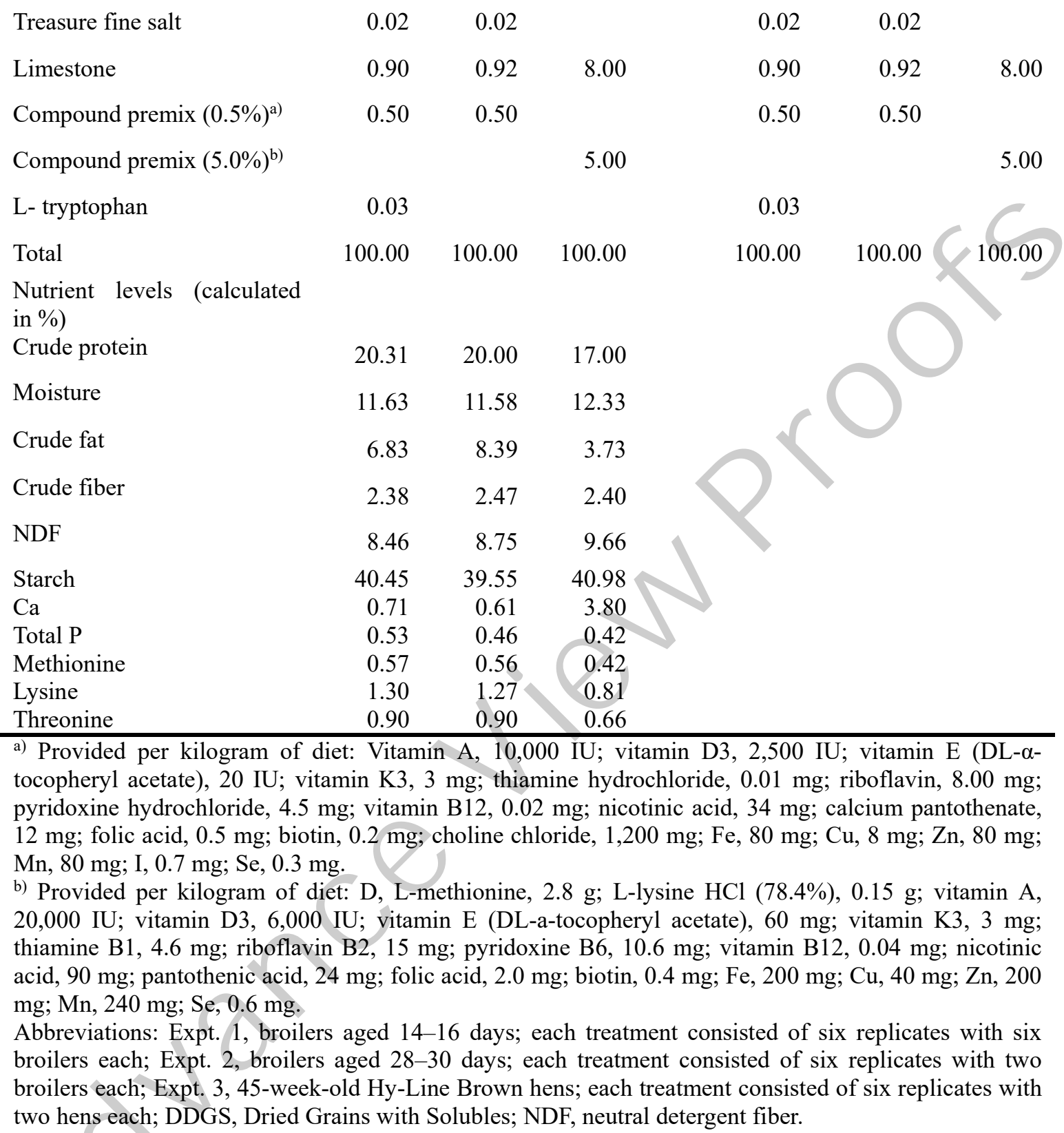


Table 2. Chemical characteristics of expanded cottonseed meal (ECSM) on a dry matter basis

\begin{tabular}{lc}
\hline Item & Value \\
\hline Crude fat (\%) & 1.08 \\
Crude protein (\%) & 54.11 \\
Ash (\%) & 10.34 \\
Crude fiber (\%) & 11.23 \\
NDF (\%) & 39.11 \\
ADF (\%) & 14.67 \\
Gross energy (kcal/kg) & 4702.96 \\
\hline Abbreviations: NDF, neutral detergent fiber; ADF, acid detergent fiber.
\end{tabular}

Abbreviations: NDF, neutral detergent fiber; ADF, acid detergent fiber. 
Table 3. Energy value and conversion efficiency of expanded cottonseed meal (ECSM) observed in the study (on a dry matter basis)

\begin{tabular}{lrrrrc}
\hline Item & Expt. 1 & Expt. 2 & Expt. 3 & SEM & P-value \\
\hline AME $(\mathrm{kcal} / \mathrm{kg})$ & $2605.85^{\mathrm{a}}$ & $2178.31^{\mathrm{b}}$ & $2782.60^{\mathrm{a}}$ & 78.32 & 0.001 \\
AMEn $(\mathrm{kcal} / \mathrm{kg})$ & $2245.19^{\mathrm{b}}$ & $1841.53^{\mathrm{c}}$ & $2629.74^{\mathrm{a}}$ & 99.15 & 0.001 \\
NE $(\mathrm{kcal} / \mathrm{kg})$ & $1655.23^{\mathrm{a}}$ & $1196.64^{\mathrm{b}}$ & $1538.19^{\mathrm{a}}$ & 55.81 & $<0.001$ \\
AME/GE (\%) & $55.39^{\mathrm{a}}$ & $46.32^{\mathrm{b}}$ & $59.18^{\mathrm{a}}$ & 1.66 & 0.001 \\
NE/AME (\%) & $63.52^{\mathrm{a}}$ & $54.93^{\mathrm{b}}$ & $55.29^{\mathrm{b}}$ & 1.41 & 0.010 \\
\hline
\end{tabular}

${ }^{\mathrm{a}-\mathrm{c}}$ Different letters indicate significant differences between the means at $P<0.05$.

Abbreviations: Expt. 1, broilers aged 14-16 days; each treatment consisted of six replicates with six broilers each; Expt. 2, broilers aged 28-30 days; each treatment consisted of six replicates with two broilers each; Expt. 3, 45-week-old Hy-Line Brown hens; each treatment consisted of six replicates with two hens each; AME, apparent metabolizable energy; AMEn, AME corrected for zero nitrogen retention; NE, net energy; GE, gross energy; SEM, standard error of the mean $(n=6)$. 
Table 4. Effect of diet composition on performance and nitrogen balance in Experiment 1

\begin{tabular}{|c|c|c|c|c|}
\hline Item & Reference diet & Test diet & SEM & P-value \\
\hline \multicolumn{5}{|l|}{ Performance } \\
\hline Body weight (g) & 567.56 & 598.43 & 5.29 & 0.011 \\
\hline Feed intake ( $g$ of $\mathrm{DM} / \mathrm{d})$ & 70.49 & 74.55 & 0.94 & 0.059 \\
\hline Body weight gain (g/d) & 57.76 & 68.68 & 3.75 & .001 \\
\hline $\begin{array}{l}\text { Feed conversion ratio }(\mathrm{g} / \mathrm{g} \text { of } \\
\mathrm{DM})\end{array}$ & 1.27 & 1.09 & 0.02 & 001 \\
\hline \multicolumn{5}{|l|}{ Respiratory parameters } \\
\hline $\mathrm{VO}_{2}\left(\mathrm{~L} / \mathrm{d} / \mathrm{kg} \mathrm{BW} \mathrm{BW}^{0.70}\right)$ & 42.19 & 43.43 & 0.46 & 0.319 \\
\hline $\mathrm{VCO}_{2}\left(\mathrm{~L} / \mathrm{d} / \mathrm{kg} \mathrm{BW}^{0.70}\right)$ & 41.36 & 40.42 & 0.37 & 0.255 \\
\hline Respiratory quotient (L/L) & 0.98 & 0.93 & 0.01 & $<0.001$ \\
\hline Nitrogen intake (g/d) & 2.53 & 3.39 & 0.08 & $<0.001$ \\
\hline Nitrogen excretion $(\mathrm{g} / \mathrm{d})$ & 0.93 & 1.39 & 0.04 & $<0.001$ \\
\hline Nitrogen retention $(\mathrm{g} / \mathrm{d})$ & 1.60 & 2.01 & 0.05 & $<0.001$ \\
\hline
\end{tabular}

Abbreviations: DM, dry matter; Expt. 1, broilers aged 14-16 days; each treatment consisted of six replicates with six broilers each; SEM, standard error of the mean $(n=6)$. 
Table 5. Effect of different diets on energy metabolism in Experiment 1

\begin{tabular}{|c|c|c|c|c|}
\hline Item & Reference diet & Test diet & SEM & P-value \\
\hline \multicolumn{5}{|c|}{ Energy balance (kcal/kg BW $0.70 / \mathrm{d})$} \\
\hline THP & 212.66 & 216.32 & 2.13 & 0.492 \\
\hline $\mathrm{HI}$ & 105.18 & 108.84 & 2.13 & 0.492 \\
\hline $\mathrm{RE}$ & 154.82 & 142.35 & 4.48 & 0.261 \\
\hline $\mathrm{RE}$ as protein & 84.53 & 102.32 & 2.28 & $<0.001$ \\
\hline $\mathrm{RE}$ as fat & 70.29 & 40.03 & 4.42 & 0.003 \\
\hline GEI & 490.63 & 495.97 & 4.58 & 0.641 \\
\hline AMEI & 367.48 & 358.67 & 3.86 & 0.358 \\
\hline NEI & 262.31 & 249.83 & 4.48 & 0.261 \\
\hline \multicolumn{5}{|c|}{ Available energy (kcal/kg of DM) } \\
\hline AME & 3508.71 & 3360.62 & 0.12 & 0.024 \\
\hline AMEn & 3496.76 & 3343.90 & 0.11 & 0.003 \\
\hline $\mathrm{NE}$ & 2503.15 & 2340.73 & 0.15 & 0.060 \\
\hline \multicolumn{5}{|l|}{ Efficiency (\%) } \\
\hline AME/GE & 74.93 & 72.35 & 0.57 & 0.063 \\
\hline NE/AME & 71.28 & 69.62 & 0.68 & 0.323 \\
\hline
\end{tabular}

Abbreviations: DM, dry matter; Expt. 1, broilers aged 14-16 days; each treatment consisted of six replicates with six broilers each; THP, total heat production; HI, heat increment; RE, retained energy; GEI, gross energy intake; AMEI, apparent metabolizable energy intake; NEI, net energy intake; AME, apparent metabolizable energy; AMEn, AME corrected for zero nitrogen retention; NE, net energy; GE, gross energy; SEM, standard error of the mean $(n=6)$. 
Table 6. Effect of diet composition on performance and nitrogen balance in Experiment 2

\begin{tabular}{|c|c|c|c|c|}
\hline Item & Reference diet & Test diet & SEM & P-value \\
\hline \multicolumn{5}{|l|}{ Performance } \\
\hline Body weight (g) & 1659.75 & 1694.21 & 17.12 & 0.347 \\
\hline Feed intake (g of DM/d) & 133.45 & 137.35 & 1.15 & 0.101 \\
\hline Body weight gain (g/d) & 104.97 & 115.14 & 6.46 & 0.016 \\
\hline Feed conversion ratio ( $\mathrm{g} / \mathrm{g}$ of $\mathrm{DM})$ & 1.27 & 1.19 & 0.03 & 0.101 \\
\hline \multicolumn{5}{|l|}{ Respiratory parameters } \\
\hline $\mathrm{VO}_{2}\left(\mathrm{~L} / \mathrm{d} / \mathrm{kg} \mathrm{BW}^{0.70}\right)$ & 37.49 & 38.37 & 0.53 & 0.444 \\
\hline $\mathrm{VCO}_{2}\left(\mathrm{~L} / \mathrm{d} / \mathrm{kg} \mathrm{BW}{ }^{0.70}\right)$ & 37.49 & & 0.31 & 0.115 \\
\hline Respiratory quotient (L/L) & 1.00 & 0.95 & 0.01 & 0.055 \\
\hline Nitrogen intake $(\mathrm{g} / \mathrm{d})$ & 4.90 & 6.22 & 0.17 & $<0.001$ \\
\hline Nitrogen excretion (g/d) & 1.75 & .58 & 0.11 & $<0.001$ \\
\hline Nitrogen retention $(\mathrm{g} / \mathrm{d})$ & 3.16 & 3.65 & 0.07 & $<0.001$ \\
\hline
\end{tabular}

Abbreviations: DM, dry matter; Expt. 2, broilers aged 28-30 days; each treatment consisted of six replicates with two broilers each; SEM, standard error of the mean $(n=6)$. 
Table 7. Effect of different diets on energy metabolism in Experiment 2

\begin{tabular}{|c|c|c|c|c|}
\hline Item & Reference diet & Test diet & SEM & P-value \\
\hline \multicolumn{5}{|l|}{$\begin{array}{ll}\text { Energy } & \text { balance } \\
\left.\mathrm{BW}^{0.70} / \mathrm{d}\right) & \end{array}$} \\
\hline THP & 189.85 & 192.02 & 2.25 & 0.656 \\
\hline HI & 82.37 & 84.54 & 2.25 & 0.656 \\
\hline RE & 158.04 & 132.29 & 4.56 & 0.002 \\
\hline $\mathrm{RE}$ as protein & 78.97 & 89.81 & 1.64 & 0.001 \\
\hline $\mathrm{RE}$ as fat & 79.07 & 42.48 & 5.30 & $<0.001$ \\
\hline GEI & 453.09 & 453.63 & 3.38 & 0.941 \\
\hline AMEI & 347.89 & 324.3 & 4.43 & 0.005 \\
\hline NEI & 265.53 & 239.77 & 4.56 & 0.002 \\
\hline \multicolumn{5}{|c|}{ Available energy ( $\mathrm{kcal} / \mathrm{kg}$ of DM) } \\
\hline AME & 3714.12 & 3413.17 & 0.18 & $<0.001$ \\
\hline AMEn & 3520.65 & 3195.81 & 0.19 & $<0.001$ \\
\hline $\mathrm{NE}$ & 2835.15 & 2524.64 & 0.20 & $<0.001$ \\
\hline \multicolumn{5}{|l|}{ Efficiency $(\%)$} \\
\hline $\mathrm{AME} / \mathrm{GE}$ & 76.78 & 71.49 & 0.81 & $<0.001$ \\
\hline NE/AME & 70.3 & 73.96 & 0.68 & 0.094 \\
\hline
\end{tabular}

Abbreviations: DM, dry matter; Expt. 2, broilers aged 28-30 days; each treatment consisted of six replicates with two broilers each; THP, total heat production; HI, heat increment; RE, retained energy; GEI, gross energy intake; AMEI, apparent metabolizable energy intake; NEI, net energy intake; AME, apparent metabolizable energy; AMEn, AME corrected for zero nitrogen retention; NE, net energy; GE, gross energy; SEM, standard error of the mean $(n=6)$. 


\begin{tabular}{|c|c|c|c|c|}
\hline Item & Reference diet & Test diet & SEM & P-value \\
\hline \multicolumn{5}{|l|}{ Performance } \\
\hline Feed intake (g of DM/d) & 82.73 & 92.64 & 2.20 & 0.044 \\
\hline Average hen daily production (\%) & 88.33 & 91.67 & 3.59 & 0.290 \\
\hline \multicolumn{5}{|l|}{ Respiratory parameter } \\
\hline $\mathrm{VO}_{2}\left(\mathrm{~L} / \mathrm{d} / \mathrm{kg} \mathrm{BW}^{0.70}\right)$ & 25.94 & 27.76 & 0.45 & 0.107 \\
\hline $\mathrm{VCO}_{2}\left(\mathrm{~L} / \mathrm{d} / \mathrm{kg} \mathrm{BW}^{0.70}\right)$ & 25.88 & 26.64 & 0.57 & 0.664 \\
\hline Respiratory quotient $(\mathrm{L} / \mathrm{L})$ & 1.00 & 0.96 & 0.01 & 0.160 \\
\hline Nitrogen intake (g/d) & 3.02 & & 0.13 & $<0.001$ \\
\hline Nitrogen excretion $(\mathrm{g} / \mathrm{d})$ & 2.09 & 2.80 & 0.12 & $<0.001$ \\
\hline Nitrogen retention $(\mathrm{g} / \mathrm{d})$ & 0.94 & 1.14 & 0.04 & 0.090 \\
\hline
\end{tabular}

Abbreviations: DM, dry matter; Expt. 3, 45-week-old Hy-Line Brown hens; each treatment consisted of six replicates with two hens each; SEM, standard error of the mean $(n=6)$. 
Table 9. Effect of different diets on energy metabolism in Experiment 3

\begin{tabular}{|c|c|c|c|c|}
\hline Item & Reference diet & Test diet & SEM & P-value \\
\hline \multicolumn{5}{|l|}{$\begin{array}{ll}\text { Energy } & \text { balance } \\
\left.\mathrm{BW}^{0.75} / \mathrm{d}\right) & \end{array}$} \\
\hline THP & 131.72 & 143.41 & 2.32 & 0.098 \\
\hline $\mathrm{HI}$ & 43.34 & 55.03 & 2.32 & 0.098 \\
\hline RE & 22.33 & 23 & 2.54 & 0.412 \\
\hline $\mathrm{RE}$ as protein & 20.46 & 25 & 1.00 & 0.029 \\
\hline $\mathrm{RE}$ as fat & 1.87 & -1.71 & 2.42 & 0.977 \\
\hline GEI & 212.54 & 245.03 & 5.71 & 0.002 \\
\hline AMEI & 154.05 & 166.49 & 3.40 & 0.074 \\
\hline NEI & 111.14 & 115.63 & 2.54 & 0.412 \\
\hline \multicolumn{5}{|c|}{ Available energy (kcal/kg of DM) } \\
\hline AME & 3050.11 & 1 & 0.10 & 0.004 \\
\hline AMEn & 2954.57 & 2825.60 & 0.09 & 0.001 \\
\hline $\mathrm{NE}$ & 2199.81 & 2037.39 & 0.18 & 0.060 \\
\hline \multicolumn{5}{|l|}{ Efficiency (\%) } \\
\hline $\mathrm{AME} / \mathrm{GE}$ & 72.47 & 67.95 & 0.69 & $<0.001$ \\
\hline NE/AME & 71.91 & 67.09 & 1.18 & 0.310 \\
\hline
\end{tabular}

Abbreviations: DM, dry matter; Expt. 3, 45-week-old Hy-Line Brown hens; each treatment consisted of six replicates with two hens each; THP, total heat production; HI, heat increment; RE, retained energy; GEI, gross energy intake; AMEI, apparent metabolizable energy intake; NEI, net energy intake; AME, apparent metabolizable energy; AMEn, AME corrected for zero nitrogen retention; NE, net energy; GE, gross energy; SEM, standard error of the mean $(n=6)$. 